\title{
Chapter 1: Weakness and IIIness - The Female Body
}

\begin{abstract}
"Tu es diaboli ianua, tu es arboris illius resignatix, tu es divinae legis prima desertrix; tu es quae eum suasisti, quem diabolus aggredi non valuit; tu imaginem dei, hominem adam, facile elisisti; propter tuum meritum, id est mortem, etiam filius dei mori habuit" Tertullian
\end{abstract}

\subsection{The Dualism of Body and Soul and the Imago Dei}

The female body is often given as the reason why women should not talk in public, be involved in politics or be able to publish their thoughts. Women and their bodies are seen as weak and prone to illness, which make them unfit to write or teach. This chapter will show the negotiations between these medieval and seventeenth century female writers and their bodies and will demonstrate how they used the stereotypes and preconceived shortcomings of their bodies as ways to legitimise their authority as producers of texts. As a starting point for the discussion on female bodies with which these female writers were confronted, one cannot avoid addressing the concept of the dualism of body and soul, which is of great importance in many religious writings. For example, "Watch and pray, that ye enter not into temptation: the spirit indeed is willing, but the flesh is weak" (Matt. 26:41) is a passage that is frequently used as a basis for writings that concern themselves with the dualism of body and soul. From the Bible onward, the body has been associated with sin, uncleanliness and all sorts of worldly temptations, while the soul (also synonymously referred to as the mind or the spirit) has been linked 
to love, faith, temperance and the ability to worship God. ${ }^{1}$ In contemplative writings in particular, the body is often seen as a prison, the one thing that ties us to the world and cannot be discarded. Augustine, for instance, states that "the body which is corrupted presses down the soul" (Chapter XVII, Book 7), while Thomas à Kempis, in an even clearer statement, notes: "So long as we carry about with us this frail body, we cannot be without sin, we cannot live without weariness and trouble" (Chapter XXII, Book 1). The body is therefore closely connected to sin and passion and thus keeps one from a perfect spiritual life. Even the bare necessities of the body, such as eating and drinking, are a distraction that keep these contemplatives, such as Richard Rolle or Thomas à Kempis, from worshipping God completely.

Furthermore, the dualism of body and soul entails the oppositions of passion and reason, humanity and divinity, as well as female and male. Women have often been seen as more susceptible to outside influences, meaning all kinds of temptations and the female body has come to be associated with passion and sin. One of the central texts, if not the central one, that is often quoted in order to demonstrate this is Genesis 1-3. Many Christian theologians not only use the creation story and the fall of Adam and Eve to show how sin and woe came to be, but also to illuminate the relationship of men and God as well as men and women. Augustine, for instance, explains Genesis and God's creation of man in his likeness in the following fashion. It is worth quoting in full:

We see the face of the earth, replete with earthly creatures; and man, created in thy image and likeness, in the very image and likeness of thee - that is, having the power of reason and understanding - by virtue of which he has been set over all irrational creatures. And just as there is in his soul one element which controls by its power of reflection and another which has been made subject so that it should obey, so also, physically, the woman was made for the man; for, although she had a like nature of rational intelligence in the

See, for instance, Galatians 19-24: "Now the works of the flesh are manifest, which are these; Adultery, fornication, uncleanness, lasciviousness, Idolatry, witchcraft, hatred, variance, emulations, wrath, strife, seditions, heresies, Envyings, murders, drunkenness, revellings, and such like [...] But the fruit of the Spirit is love, joy, peace, longsuffering, gentleness, goodness, faith, Meekness, temperance: against such there is no law. And they that are Christ's have crucified the flesh with the affections and lusts." Especially interesting is the fact that while witchcraft and heresies are connected to the body, the mortification of the flesh is associated with Christ's suffering on the cross. 
mind, still in the sex of her body she should be similarly subject to the sex of her husband, as the appetite of action is subjected to the deliberation of the mind in order to conceive the rules of right action. (Chapter XXXII, Book 13)

Augustine here comments on the imago dei and along with many other writers, he associates the likeness of the image with reasoning and the faculties of the mind and not with the body. The emphasis on rationality versus irrational beasts thus establishes the hierarchy of all the creatures on earth. Naturally, women are subordinated to men as well. Although Augustine states that women have "a like nature of rational intelligence in the mind," and with that he seemingly solves the problem of Genesis $1: 27^{2}$, women are still inferior in their faculties and should follow men by engaging in the "right action." Interestingly enough, when it comes to women physicality and the body are suddenly grounds for discussion. She is not only inferior in her faculties, but her body is also subjugated to men. The simile at the end of the quotation, furthermore, connects the female body with "the appetite of action" and, consequently, starts the associations of body and appetite, passion and $\sin$.

Comments on imago dei often do not include women, especially if the Fall is used as an argument as to why women are not created in the likeness of God. Many of these interpretations are also much more derogatory than Augustine's. Tertullian, for instance, who wrote on a variety of theological issues in Latin, states: "Tu es diaboli ianua, tu es arboris illius resignatix, tu es divinae legis prima desertrix; tu es quae eum suasisti, quem diabolus aggredi non valuit; tu imaginem dei, hominem, tam facile elisisti; propter tuum meritum, id est mortem, etiam filius dei mori habuit" (Chapter I, Book 1). ${ }^{3}$ From Tertullian's point of view, Eve alone is guilty. It is she who is weak, having given in to temptation and is accordingly punished with death. Furthermore, in calling Adam the image of God, Tertullian makes it clear that he does not

"So God created man in his own image, in the image of Cod created he him; male and female created he them." This account of Cenesis implies that men and women are equally created in Cod's image.

Tertullian is often quoted when it comes to Eve and the relationship of men and women and her subjection to men. See, for example, Sandra J. McEntire's English translation of Tertullian's passage in her essay "The Likeness of Cod": "You are the devil's gateway; you are the unsealer of that tree; you are the first foresaker of the divine law; you are the one who persuaded him whom the devil was not brave enough to approach; you so lightly crushed the image of Cod, the man Adam; because of your punishment, that is, death, even the Son of Cod had to die" (167). 
consider Eve to be made in God's image. Consequently, Eve is the only one to blame for the death of Christ. As seen in Augustine's quote above, in the bipartite soul system, the imago dei is connected to the mind/spirit and man and in contrast the body is connected to woman. With reference to Tertullian's comment on the Fall, Eve is not made in God's image and is responsible for sin entering the world. Accordingly, the body, which is connected to sin and passion, seems to be strongly associated with women and needs to be subjugated to the mind and to men.

Even Walter Hilton (c. 1343-1396), a mystic and contemporary of Julian of Norwich who propagated the mixed life, followed Augustine's bipartite system and subordinated the bodily to the spiritual. In his Epistle on the Mixed Life, Hilton opens the way for a life between the via contemplativa and the via activa. Since the via activa is seen as inferior and the contemplative life only open to a few recluses, the mixed life was meant to enable a middle class toward leading a spiritual life despite their obligation to concern themselves with worldly matters. ${ }^{4}$ Thus, according to Hilton, a spiritual life was possible without forsaking the bodily realm entirely. However, it becomes clear that although middle and upper class people are responsible for their family and servants and, thus, have to deal in worldly matters, Hilton associates the body with sin as well. According to him, one needs "to break down the disobedience of the body" and "as St Paul says, as woman was made for man, and not man for woman, just so bodily work was made for the spiritual" (Epistle on the Mixed Life 105). In Hilton's The Scale of Perfection, which he wrote for an anchoress, this notion becomes even more explicit: "and as your body is enclosed from bodily association with men, just so should your heart be enclosed from the fleshly loves and fears of all earthly things" (Chapter I, Book 1). In describing the active life and its works again in contrast to the contemplative life, Hilton states: "Moreover, a part of the active life lies in great bodily work one does to oneself, such as great fasting and denial of sleep, and other sharp acts of penance, in order to chastise the flesh" (Chapter II, Book 1). Although one can achieve spirituality through an active life, Hilton's negative stance toward the body becomes apparent. Similar to Augustine's passage above, Hilton also

The mixed life seems to have been popular in fourteenth and fifteenth century England, as evidenced not only in Hilton's work, but also in other texts. See, for instance, the 'common profit' books which were "made for the new context of a community of devout London lay people" (Scase) or Pantin "Instructions for a devout and literate layman." 
connects the subordination of women to men with the subordination of the body to the spirit, associating the body through analogy with women.

Thus, the body and by extension women are often connoted negatively. Indeed, Dyan Elliott states: "In short, whether orthodox or gnostic, a woman had to deny her nature to advance spiritually“ (16-17). Curiously however, Julian of Norwich (1342-c.1416) does not deny her body, managing instead to include it positively in her theology. Most of what we know about Julian comes from her Showings, an account and reflections about her sixteen revelations that she received in 1373 at the age of thirty and a half. She is, furthermore, described as an anchoress ${ }^{5}$ and, thus, a voluntary recluse who is enclosed for life. "Anchorite enclosure was considered the highest religious calling. [...] By the fourteenth century, according to books of guidance composed for anchorites by Richard Rolle, Walter Hilton, [...] contemplative or mystical union with God was the ultimate goal of the recluse" (Denise N. Baker, "Introduction" x). Moreover, Julian shares her mystical union, the sixteen revelations, not only with the learned, but addresses her Showings to all "evyn Cristen" - "I say nott thys to them that be wyse, for they wytt it wele. But I sey it to yow that be symple, for ease and comfort, for we be alle one in love" (Showings 16). Thus, just like Walter Hilton's Mixed Life, Julian's Showings speaks to a growing audience of devout lay people.

Julian's revelations also comment on many theological issues, among which the dualism of body and soul is of special interest here. According to Julian, "Hyely owe we to enjoye that God dwellyth in oure soule, and more hyly we owe to enjoye that oure soule dwellyth in God. Oure soule is made to be Goddys dwelling place, and the dwellyng of oure soule is God, whych is unmade" (Showings 84). Thus, for Julian, God is in our soul and our soul is in God. This means that the imago dei in her theology is rooted in a bipartite soul system, just as it is for Augustine and many others. For her the soul is divided into 'substance' and 'sensuality', whereby substance is the equivalent to Augustine's higher part of the soul, the part in which reasoning and rationality is possible. Indeed, Julian maintains that she "sawe no dyfference betwen God and oure substance," as this substance is a part of God (Showings 84). However, the important difference between Julian's

See, for instance, Margery Kempe: "And than sche was bodyn be owyr Lord for to gon to an ankres in the same cyte, whych hyte Dame Jelyan. [...] many wondirful revelacyons whech sche schewyd to the ankres to wetyn yf ther wer any deceyte in hem, for the ankres was expert in swech thyngys and good cownsel cowd yevyn" (120). 
imago dei and Augustine's is that in hers the bodily is not condemned: "Thus I understode that the sensuallyte is groundyd in kynde, in mercy, and in grace, whych ground ablyth us to receyce gyftes that leed us to endlesse lyfe. For I saw full suerly that oure substaunce is in God, and also I saw that in oure sensualyte God is" (Showings 85). As far as Julian is concerned, our sensuality is based on kindness, mercy and grace and it plays an important part in salvation. Thus, despite the separation in Julian's soul system, akin to that of Augustine, it differs from the latter in that sensuality and the body are also part of the imago dei.

\subsection{Affective Piety and the Mystical Experience}

As a consequence, by linking the body to sin and thereby to women, the focus on the positive aspects of the bodily seems to be far more important for women than for men. However, the importance of the body, in one way or another, is part of the mystical tradition of 'affective piety' to which Julian, Rolle, Hilton and Margery all belong. 'Affective piety' is the emotionally charged meditation on Christ's Passion and it focuses not only on Christ's suffering but also on his humanity. Both his humanity and his body take centre stage. At the same time, the bodily experiences of the mystics themselves are significant. Through their bodies, they are able to feel Christ's suffering and be part of his Passion, thereby achieving a higher spirituality and personal connection to God. Indeed, Anselm, Rolle and Hilton all have extensive passages in which they describe their experience of the Passion. Most of these accounts are very detailed and concentrate heavily on the body. For example, Anselm (1033-1109) was abbot of Bec and archbishop of Canterbury and his Prayers and Meditations is one of the foundational texts of 'affective piety'. His personal and devotional style and his prayers in the form of a dialogue influenced many later writers. Sentences directed to God like "I thirst for you, I hunger for you, I desire you, I sigh for you, I covet you" (94) and Passion scenes such as "I am mindful of your passion, your buffeting, your scourging, your cross, your wounds, how you were slain for me, how prepared for burial and buried" (95) are later taken up by many mystics such as Rolle, Hilton, Margery and Julian.

Julian, for instance, wishes for three gifts at the beginning of her treaties. The very first is "mynd of the passion" (Showings 5) and her first revelation begins with the following words: "And in this sodenly I saw the reed bloud rynnyng downe from under the garlande, hote and freyshely, plentuously and 
lively, right as it was in the tyme that the garland of thornes was pressed on his blessed head" (Showings 8). In her writings, the notion of a mystical union with God is a very personal one and the desire for, and, indeed, the love of, God is central. The Passion scene is often used as a beginning for contemplation, as the humanity and fleshliness of Christ on the cross seems to function as a bridge to a higher spirituality. Even though Anselm, Hilton and Rolle also use images of sinners being imprisoned in their own bodies and yet being able to connect with God on a higher contemplative level through Christ's humanity, Julian and Margery embrace and use these images particularly frequently. This is perhaps because the close connection between the mystics' bodies and Christ's body gives these women an opening to attain spirituality at a time when their bodies and their 'nature' would ordinarily have been condemned and connected to sinfulness.

Margery Kempe also belongs to the mystical tradition of affective piety. Most of what we know about her comes from her Book, which is often called the first autobiography in English. Since the discovery of the manuscript in 1934, she and her text have sparked a wide variety of commentary. Although The Book of Margery Kempe was not known until the manuscript was found, Kempe's name appeared on a seven-page pamphlet printed by Wynkyn de Worde in 1501 called Here begynneth a shorte treatyse of contemplacyon taught by our lorde Jhesu cryste, or taken out of the boke of Margerie kempe oflynn. As the pamphlet mostly contains Christ's speech to Margery and thus excludes her vivid life and her extraordinary voice, Henry Pepwell, who reprinted the text in an anthology of mystical pieces in 1521, calls Margery "a devoute ancres" (Windeatt, "Introduction" 1). Thus, the rediscovery of the Book in 1934 was accompanied by expectations that the whole book would be, as Pepwell says, by a devout woman, probably even similar to Julian of Norwich's Showings. The Book, however, does not seem to have met those expectations and this becomes apparent in early criticism in which one can sense clear disappointment. David Lawton states that many critics agree that Margery failed

and their sense that the failure and the exclusion require explaining. The explanations have fluctuated between eccentricity - on a sliding scale of hysteria, unreliability, religious megalomania, even paranoid schizophrenia - and, on the other hand, heterodoxy, or blasphemy, of the type that canon law calls indirect. (94)

According to Sandra J. McEntire, not only is Margery seen in criticism as "unconventional, mediocre, mad, sensational, monotonous, hysterical, ab- 
normal, trivial, and even morbid" ("The Journey" 51), but she also does not seem to fit into any one convention or genre. Alternately, she is called a mystic or a heretic and her Book a hagiography or an autobiography. Margery Kempe does avail of these genres and conventions but she ultimately defies them and establishes an agency and voice of her own accordingly.

For instance, in describing her mystical experience, she draws heavily from the mystical tradition available to her. In her Book, she states that a priest came to her and read books to her for seven or eight years. "He red to hir many a good boke of hy contemplacyon and other bokys, as the Bybyl wyth doctowrys therupon, Seynt Brydys boke, Hyltons boke, Boneventur, Stimulus Amoris, Incendium Amoris, and swech other" (280). Apart from the Bible, Margery mentions a book by St. Bridget of Sweden (1303-1373), who must have been an interesting visionary for her given that she was also married, a mother and a pilgrim who found God later in life. Indeed, the importance of St. Bridget for Margery is apparent from the frequency with which she is mentioned in the Book and from the fact that Margery even visits the places in Rome where St. Bridget lived. At one point Margery finds a certain degree of agency in her similarities with St. Bridget while providing proof for the truth of St. Bridget's book: "Than seyd owyr Lord ayen to hir: 'Ther schal be an erdene. Tel it whom thow wylt, in the name of Jhesu. For I telle the forsothe, ryght as I spak to Seynt Bryde, ryte so i speke to the, dowtyr, and I telle the trewly, it is trewe every word that is wretyn in Brides boke, and be the it schal be knowyn for very trewth" (129-130). In this extract, Margery validates both St. Bridget's writings and her own power and status as a visionary. However, she makes sure that she is seen as being even more graced by God than St. Bridget. Shortly before this passage, she is attending mass and she sees the sacrament move and flutter like a dove with its wings in the priest's hands. Still marvelling at this occurrence, Margery hears Christ telling her: "Thow schalt no mor sen it in this maner; therfor thank God that thow hast seyn. My dowtryr, Bryde, say me nevyr in this wyse" (129). In claiming that St. Bridget never saw Him in this way, Margery gains special status as God's mouthpiece.

Margery also includes Hilton and the Incendium Amoris in her list of "many a good boke." The Incendium Amoris was written by Richard Rolle (c. 1305-1349) who was a hermit and mystic. Most of what we know of him stems from references in his own writings as well as what the Hampole nuns wrote thirty years after his death (Hughes). According to Watson, "[d]uring the fifteenth century he was one of the most widely read of English writers, whose works survive in nearly four hundred English (or American) and at least seventy 
Continental manuscripts, almost all written between 1390 and 1500" (Richard Rolle 31). Rolle's popularity and his descriptions of his mystical union with God make him the perfect writer to emulate. Indeed, Margery twice mentions that Incendium Amoris ${ }^{6}$ had been read to her. Rolle's writings also serve as proof for the scribe who has lost faith in Margery's possessing the grace of God. ${ }^{7}$ Margery does more than reference Rolle, she incorporates several elements from his writings in order to give greater credibility to her own union with God. Though these include references to both fragrance and melody, ${ }^{8}$ the clearest acknowledgement of his work is her repeated use of the term "fyre of love." This fire of love is described in Rolle's Incendium Amoris as well as in The Form of Living, in which he talks about three degrees of love, whereby the third, and highest, is described in the following way:

pe thyrd degre es heest, and maste ferly to wyn, pat es calde synguler, for it hase na pere. Singuler lufe es, when all comforth and solace es closed owt of pi hert, bot of Jhesu Cryste alane. Other joy lyst it noght, for pe swetnes of hym in pis degre es swa comfortand and lastand in his lufe, sa byrnand and gladand, pat he or scho, pat es in pis degre, mai als wele fele pe fyre of lufe byrnand in paire saule, als pou may fele pi fynger byrn, if pou putt it in pe fyre. (The Form of Living 105)

This third degree is the aim of contemplation. It is the highest, purest and most difficult degree that one can attain. ${ }^{10}$ By comparing the feeling of the fire of love in the soul to the sensation of a finger in a fire, Rolle describes an almost bodily experience that bridges the physical with the spiritual in the union of the mystic and God.

See on p. 115 and 280.

"He red also of Richard Hampol, hermyte, in Incendio Amoris leche mater that mevyd hym to yevyn credens to the sayd creatur" (295-296).

See, for example, p. 137: "I schal take thi sowle fro thi body wyth gret myrthe and melodye, wyth swet smellys and good odowrys, and offyr it to my Fadyr in hevyn."

See, for example, pages 97, 166-67, 193-94,285, 334 and 361.

See also Hilton when he speaks about the highest degree of contemplation: "No one can have the practice and full use of this gift without being first reformed to the likeness of Jesus by fullness of virtue. I suppose no one living in a mortal body can have it often in its fullness, but occasionally, when he is visited; and as I conceive from the writings of holy men, it is for a very short time, for soon afterward he lapses into sobriety of bodily feeling" (The Scale of Perfection, Chapter VIII, Book 1). Here, again, Hilton draws attention to the negative aspects of the body. 
Hence, Margery, who is able to feel this fire of love throughout the Book, has attained this third and highest degree of love and is able to legitimise her mystical experience through Rolle's directions in The Form of Living. Indeed, at one point, she describes the fire of love in more detail:

Also owr Lord yaf hir another tokne, the whech enduryd abowtyn xvi yer, and it encresyd evyr mor and mor, and that was a flawme of fyer, wondir hoot and delectabyl and ryth comfortabyl, nowt wastyng but evyr incresyng, of lowe, for, thow the wedyr wer nevyr so colde, sche felt the hete brennyng in hir brest and at hir hert, as verily as a man schuld felyn the material fyer yyf he put hys hand or hys fynger therin. (193-194)

The two descriptions are strikingly similar. Not only are the same adjectives used, such as comfortable and burning, Margery even uses the same analogy as Rolle in claiming that the heat is felt just as it would be if one were to put a finger into a fire. In Margery's case, however, the description is even more bodily than in Rolle's. She feels the heat in her breast and in her heart and she even mentions the weather to imply that the heat would be able to warm her if necessary. In this way, the fire of love is felt in the soul as well as the body. The body is not negated here, instead it plays an important role as part of the mystical union between Margery and God.

Moreover, although Rolle suggests that this degree is only attainable after long and serious contemplation in a solitary cell, ${ }^{11}$ Margery obtains it without having been an anchorite or resorting to living in seclusion. Karma Lochrie thus states: "Kempe remains one of the most problematic of mystics, English or continental, because of her very mobility and unbridled mystical practices" (88). In contrast to other mystics, who are either nuns, hermits or anchorites, Margery is very mobile, travelling throughout England and going on pilgrimages to Jerusalem, Rome and Santiago de Compostela. Furthermore, Staley suggests that: "whereas in devotional treatises like The Cloud of Unknowing or Rolle's Incendium Amoris [...] we find manuals of spiritual instruction that are intended to guide the fledgling contemplative, Kempe offers no sense that Margery's experience might be duplicated by another devout woman or be seen as exemplary and therefore available" (98). However, despite Margery's

Rolle's extreme notions for the solitary life have been, for example, countered by Walter Hilton. "He warned Rolle's followers about interpreting canor in too literal a sense, advising them not to neglect their families and their social responsibilities by becoming hermits" (Hughes). 
mobility, she still uses features and conventions that are typical of mystical writings in order to validate both herself and her life. Indeed, in contrast to what Staley states, Margery's Book can be seen as both exemplary and instructive: "Alle the werkys of ower Saviowr ben for ower exampyl and instuccyon, and what grace that he werkyth in any cratur is ower profyth" (41). Thus, God's grace as manifested in Margery (as she reassuringly tells us again and again) serves as an example, while the life she lives serves as a form of instruction. After all, God commands her to write "hyr felyngys and revelacyons and the forme of her levyng, that hys goodnesse myth be knowyn to alle the world" (47, my emphasis).

Margery's mobility and her ability to feel the fire of love for a prolonged time stands in stark contrast to Rolle and Hilton's notion of contemplation. Her example seems much more inclusive and shows that a laywoman can achieve the highest degree of contemplation. Even though her Book is not constructed as a manual per se, it serves as an example and appeals to a more inclusive audience than just recluses, hermits and the audience of Hilton's mixed life. Similarly, Julian's notion of the imago dei and her insistence on addressing "all" Christians speaks of a more inclusive audience as well, even though Julian herself is an anchoress. Despite the fact that Rolle maintains that his writing is aimed at the simple and the unlearned, his claim can be seen merely as a means by which to critique learned theologians and philosophers. He states: "I offer, therefore, this book for the attention, not of the philosophers and sages of this world, not of great theologians bogged down in their interminable questionings, but of the simple and unlearned, who are seeking rather to love God than to amass knowledge" (The Fire of Love 46). In his view, theologians amass too much knowledge and are, thus, too heavily invested in the world to understand the ardent love that he feels towards God. He takes the view that one needs to leave behind everything belonging to the world in order to devote oneself completely to the love of God (The Fire of Love 47). Thus, Rolle's work serves as a manual for hermits or contemplatives, that is, for those who follow a solitary life devoted to God, as can also be seen by the aforementioned The Form of Living, which is addressed to a young female recluse (82). Furthermore, as described above, the highest degree of contemplation can only be achieved by a few, at least according to Rolle and Hilton. It seems curious then that both women, marginalised for their gender, tend to speak to a broader audience than their contemporary male authors.

Margery uses Rolle as an example of the fire of love and similarly includes affective piety in her Book. In his Longer Meditations, Rolle meditates on Christ's 
Passion and uses several quite peculiar analogies for Christ's wounds. One is as follows: "Once more (a comparison), sweet Jesu: Your body is like a dovehouse, because, just as a dovecote is full of openings, so your body is full of wounds" (113). ${ }^{12}$ This dove-cote is also picked up by Margery in one of her meditations on the Passion:

Sche had so very contemplacyon in the sygth of hir s[owle] as yf Crist had hangyn befor hir bodily eye in hys manhode. And whan thorw dispensacyon of the hy mercy of owyr Sovereyn Savyowr, Crist Jhesu, it was grawntyd this creatur to beholdyn so verily hys precyows tendyr body - alto-rent and toryn wyth scorgys, mor ful of wowndys than evyr was duffehows of holys, hangyng upon the cross wyth the corown of thorn upon hy hevyd. (166-167)

A well as using the same analogy, Margery avails of all the important features of a Passion meditation. She concentrates on Christ made flesh and thus with her bodily eyes is able to see the Passion scene.

Furthermore, what mystics often wish for is to be present at the Passion, seeing and grieving with Christ's mother. Rolle is the perfect example of this: ${ }^{13}$ "O sweet lady, why could I not have been beside you, hearing what you were hearing, seeing that scene right beside you, taking my share of that tremendous grief, perhaps being able to alleviate your misery? After all, people say it is a consolation to have a companion in trouble" (The Longer Meditations 121). ${ }^{14}$

12 The dove can be interpreted in different significant ways throughout the Bible, but Rolle's analogies seem to be meant as common day-to-day experiences that everybody can understand. In this analogy, for instance, the dove is safe from the hawk in the dove-house and he compares the wounds also to the stars, a net, a honeycomb, a book and a meadow (Longer Meditations 112-114). Margery does something similar in a dialogue between her and Christ: "Dowtyr, for thu art so buxom to my wille and clevyst as sore onto me as the skyn of stokefysche clevyth to a mannys handys whan it is sothyn" (197).

13 See also Julian's description: "Me thought I woulde ben that tyme with Magdaleyne and with other that were Christus lovers that I might have seen bodilie the passion that our Lord suffered for me, that I might have suffered with him as other did that loved him. And therefore I desyred a bodely sight wher in I might have more knowledge of the bodily paynes of our Saviour and of the compassion of our Lady and of all his true lovers that were lyviyng that tyme and saw his payne. For I would have be one of them and have suffered with them" (Showings 4). In addition to the typical references, the constant use of "bodily" is astounding.

14 See also Anselm: "Why, O my soul, were you not there to be pierced by a sword of bitter sorrow [...] Why did you not see with horror the blood that poured out of the side of 
Margery's Book, on the other hand, goes much further. It is as Barry Windeatt states:

When Kempe mentions to Richard Claister some spiritual classics she knows, 'Hyltons boke, ne Bridis boke, ne Stimulus Amoris, ne Incendium Amoris' (17: 39), it is not simply to list her devout reading for its own sake. Margery Kempe's project is bolder: she measures her experience against these classics only to assert her superior authority and originality, claiming that her own inward confabulations with the divine, if only she could express them, are unmatched by any such texts she ever heard read, in speaking of the love of Cod. ("Introduction" 6)

Whereas Rolle would have liked to have been at the Passion scene and to have shared Our Lady's sorrow, Margery actually gets to experience it. She not only sees the Passion with her bodily eyes, she even participates in it. She is the one who says to the Lady: "I prey yow, Lady, cesyth of yowr sorwyng, for yowr sone is ded and owt of peyne, for me thynkyth ye han sorwyd anow. And, Lady, I wil sorwe for ow, for yowr sorwe is my sorwe" (350). Interestingly, Margery even commands the Blessed Virgin to stop being sorrowful and in the end she quite literally takes over Mary's sorrow by crying, screaming and running around herself. She even brings Christ's mother a hot drink to comfort her (352). Akin to her usage of the fire of love, Margery makes clear that she is singular and that she has a special grace from God. She cleverly uses several features, such as the fire of love, the Passion scene and the dialogues with Christ in order to connect herself to other established mystics, such as Rolle, and by so doing gives authority to both herself and her Book. In contrast to the male writers, Margery and Julian emphasise the bodily. It seems much more important for them to include their bodies positively in their union with God. Julian not only stresses her bodily experience in the Passion scene, but also includes the body in her imago dei in which God is in the substance as well as in the sensuality. In Margery's case, everything that she does, she does with her whole body. Her fire of love is a real bodily sensation and she is present at and participates in the Passion scene. The gift of her crying and the pain that she experiences when thinking of the Passion both include her whole body and are clear for everyone to see. Both of these mystics negate the negative

your Redeemer? [...] Why did you not share the sufferings of the most pure virgin, his worthy mother and your gentle lady?" (95). 
conventions around female bodies and are able to legitimise themselves as visionaries in their writings. ${ }^{15}$

\subsection{Illness and Weakness as a Rite of Passage}

Another way in which these female visionaries gain authorisation and find their own voice is through illness and weakness, which are similarly related to the body. Women are seen as weak and prone to illness, which forms the basis of arguments that they are unfit for politics, thinking or public speaking. Diane Purkiss, for instance, states: "In the seventeenth century, illness and bodily weakness were feminized. Women were thought to be particularly prone to illness, and illness and weakness were in turn negative signs of femininity, underwriting woman's subordination" (144). Many female visionary writers still saw the need to defend themselves and, thus, included negative stereotypes, such as being weak and prone to illness, in their texts. Interestingly, these epithets, weakness and illness, are used by the visionary writers to establish their authority and authorship, as we have already seen with Margery and Julian. As weak and humble beings, they are the perfect vessels and instruments of God and are thus able to utter divinely inspired truths.

Anna Trapnel (fl. 1642-1660), for instance, fell into a twelve-day trance in January 1654 while she was at Whitehall supporting Vavasor Powell, who was being investigated for treason. During her trance, she was visited by many important people and her utterances were taken down by a scribe who was

As mystics often focus their attention on contemplation as the highest level to communicate with God, the body often becomes obsolete, as seen with Hilton or Rolle. This probably led Paul Maltby to contrast the notion of epiphany with the mystics' visions. He maintains: "Finally, in the visions of the religious mystics, for example, the "shewings" or apparitions experienced by Julian of Norwich or Margery Kempe, nothing is physically sensed; the source of the vision is purely internal and sometimes physically induced by bodily abuse (starvation or flagellation) or illness. On the other hand, the literary moment may be triggered by an external stimulus: for example an overheard comment [...] or a smell" (19). However, I do not agree with Maltby that "nothing physically is sensed" in the visions of these mystics, as the body is of importance. Rolle, for instance, feels the heat of Cod's love physically, and Margery's visions are clearly felt physically as well, as I have shown above. Even though Hilton and Rolle have a negative stance towards the body, contemplation starts with the body and the female visionaries use their bodies to connect with Cod and attain their visionary status. 
present most of the time (The Cry of a Stone 1-3). Trapnel's prophecies ${ }^{16}$ are not only personal but also political, as she was part of the Fifth Monarchist movement, which was based on millenarian ideas drawn mostly from the books of Daniel and Revelation, namely that the second coming of Christ and his rule on earth were imminent and that it was time to prepare for the establishment of the New Jerusalem in England. ${ }^{17}$ Interestingly, the first thing that Anna Trapnel reveals to us after her name and those of her family and acquaintances is the illness that she had suffered seven years previously:

Seven years ago I being visited with a feaver, given over by all for dead, the Lord then gave me faith to believe from that Scripture. After two days I will revive thee, the third day I will raise the up, and thou shale live in my sight: which two days were two weeks that I should lye in that feaver, and that very time that it took me that very hour it should leave me, and I should rise and walk, which was accordingly. (The Cry of a Stone 3)

The near-death experience brought on by Trapnel's illness brings her nearer to God. Indeed, her rite of passage towards becoming a true prophet is marked by her quoting scripture ${ }^{18}$ and by her hearing God's testimony that after the illness she will live in his sight. Illness here is not the negative characteristic of a woman. Rather, it is something sent by God, who singles Trapnel out in order to make her into a prophet and an instrument of His will.

Although Purkiss states that "illness and bodily weakness were feminized" in the seventeenth century, becoming a female prophet as a result of ill health was already a common feature in the visionary writings of medieval women. Julian of Norwich receives her sixteen revelations in 1373 during a severe illness. She tells us: "And when I was xxxth yere old and a halfe, God sent me

The Oxford English Dictionary defines prophecy as " $[\mathrm{t}]$ hat which is done or spoken by a prophet; the action or practice of revealing or expressing the will or thought of Cod or of a god" and more importantly a "divinely inspired utterance or discourse." Anna Trapnel's prophecy is, thus, meant as divinely inspired and an expression of the will of God.

17 See Graham p.12 or Hinds The Cry of a Stone p. xxvii.

18 Hosea 6:1-2: "Come, and let us return unto the LORD: for he hath torn, and he will heal us; he hath smitten, and he will bind us up. After two days will he revive us: in the third day he will raise us up, and we shall live in his sight." For Trapnel, the duration of three days does not seem to be binding. Although it took her two weeks, she still believes the sickness to have been sent by God and that she was healed as a sign of His grace. 
a bodily sicknes, in the which I ley iii daies and iii nyghtes. ${ }^{19}$ And on the iiii nyght I toke all my rightes of holie church and went not to have leven tyll day. And after this I lay two daies and two nightes. And on the third night I weenied often tymes to have passed, and so wenyd thei that were with me" (Showings 6). The bodily sickness is sent to Julian by God, enabling her to receive the sixteen revelations that are then written down and intended for all Christians. The same holds true for Margery Kempe. In the first chapter of her Book, we learn that, after giving birth to a child, Margery "was labowrd wyth grett accessys" (52) and that "this creatur went owt of hir mende and was wondyrlye vexid and labowryd wyth spyritys half yer, viii wekys and odde days" (54). During this time of sickness and madness, Margery is visited by Christ telling her that he has never forsaken her. "And anoon, as he had seyd thes wordys, sche saw veryly how the eyr openyd as brygth as ony levyn [...] And anoon the creature was stabelyd in hir wyttys and in hir reson as wel as evyr sche was beforn [...] Sythen this creatur dede alle other ocupacyons as fel for hir to do wysly and sadly inow" (56). Again, the sickness sent by God marks the beginning of a journey as a visionary and as an instrument of God. Thus, although sickness and weakness have traditionally been negatively connoted in characterisations of women, the female visionaries describe them as Godsent, thereby portraying their weak and sick bodies as perfect sites for divine inspiration.

\subsection{Childbirth}

Thus, in contrast to male writers, such as Anselm, Hilton or Rolle, many female writers experience a bodily sickness before they establish themselves as prophets. Male writers are also concerned with their bodies of course but they do not begin writing as a result of their sickness or dwell on their weak bodies to the same extent women do. Indeed, one 'sickness' that is solely experienced by women is of particular interest here - namely childbirth. As seen above, Margery's sickness and her beginnings as a visionary are closely related to childbirth, an event that can not only end in death, but can also be seen as sickness itself, or be followed by sickness or even madness. As was the case

19 The mention of the three days and three nights, connects Julian with the resurrection of Christ: "For as Jonas was three days and three nights in the whale's belly; so shall the Son of man be three days and three nights in the heart of the earth" (Matthew 12:40). 
in the discussion above about the imago dei and Eve's connection to passion and sinfulness, childbirth and its pains are considered direct consequences of Eve's transgression: "Unto the woman he said, I will greatly multiply thy sorrow and thy conception; in sorrow thou shalt bring forth children; and thy desire shall be to thy husband, and he shall rule over thee" (Genesis 3:16). In Eve's punishment, pain in childbirth is connected to her subjugation to her husband. However, although childbirth is connected to pain, suffering and sickness, it is both a curse and also a path to redemption. This connection can be seen in 1 Timothy 2:13-15: "For Adam was first formed, then Eve. And Adam was not deceived, but woman being deceived was in the transgression. Notwithstanding she shall be saved in childbearing, if they continue in faith and charity and holiness with sobriety." Pain in childbearing is her punishment, but it is also how Eve is saved, suffering through it to ensure the continuance of the human race.

Moreover, this connection between childbearing and redemption is associated with Christ's suffering on the cross. Following the previous discussion on mystics reliving the Passion scene, childbirth and motherhood constitute another link that is often made between women and Christ's suffering. Anselm's assertions in his prayer to Paul are relevant here:

Truly, Lord, you are a mother, for both they who are in labour and they who are brought forth are accepted by you. [...] It is by your death that they have been born, for you had not been in labour, you could not have borne death; and if you had not died, you would not have brought forth. For, longing to bear sons into life, you tasted of death, and by dying you begot them. (153)

Anselm takes up Paul's statement in Galatians 4:19: "My little children, of whom I travail in birth again until Christ be formed in you." After comparing Paul to a mother, his prayer culminates in the above quoted passage, describing Christ as the ultimate mother who in death brings forth children. Jesus' suffering on the cross and his dying are therefore compared to childbirth and bring redemption to the children who are born through his sacrifice.

Julian's first revelation has also been interpreted as a childbirth sequence, with comparisons being made between this scene and the Passion of Christ (Park 33). Indeed, according to Park, Julian brings together Incarnation, Passion and birth in death (37). However, I disagree with Park's interpretation that this first revelation is a childbirth scene. It is true that Julian experiences a shortness of breath and a feeling of numbness beginning from her legs upwards (Showings 6-7) and, thus, the pain and the bodily site of the Passion 
are similar to those in descriptions of other Passion scenes but there is no clear connection to childbirth per se. The links to Christ's Passion are clearer as Julian is linked to Jesus' resurrection by lying sick in bed for three days and three nights. In addition, the link becomes even more apparent in what Denise N. Baker calls Julian's "astonishing comparison of Jesus to a mother" ("Introduction" xv). Indeed, in her XIV. Revelation, Julian develops her theodicy by comparing Jesus to a mother and describing his three forms of motherhood: "The furst is grounde of oure kynde makyng. The seconde is takyng of oure kynde, and ther begynnyth the moderhed of grace. The thurde is moderhed in werkyng, and therin is a forth spredyng by the same grace of lenght and brede, of hygh and of depnesse without ende. And alle is one love" (Showings 93). In her opinion, "[t]he moder's servyce is nerest, rediest, and suerest" (Showings 94) and Julian compares Jesus to a mother who gives her child milk to suck (Showings 94) and who helps frightened and hurt children, but is also wise and an educator (Showings 96). Though there is not the space here to examine all the implications of Julian's comparison and her theodicy in detail, the link between motherhood and Christ's Passion is clear throughout her deliberations. For instance, instead of a mother who lays her child to her breast, Jesus "homely lede us in to his blessyd brest by his swet opyn syde and shewe us there in perty of the Godhed and the joyes of hevyn with gostely suernesse of endlesse blysse" (Showings 94). The link is even clearer in the following statement: "And in the takyng of oure kynd he quychyd us, and in his blessyd dyeng uppon the crosse he bare us to endlesse lyfe" (Showings 99). As with affective piety, in which, through Christ's humanity, the mystic connects with God on a higher contemplative level, the association between Christ's dying on the cross and giving birth to endless life gives women and childbearing another form of authorisation that cannot be imitated by men. ${ }^{20}$

Purkiss' claim that sickness and illness were feminised in the seventeenth century is further substantiated by Louis Schwartz in his study on maternal mortality at that time: "the frequency and difficulty of birth in early modern England caused a great deal of sickness among women, who were far more often sick than men, and often chronically so" (45). He further states that " $[t]$ here is also evidence that anxieties about mortality, morbidity, and disfiguration

20 Paul does compares himself to a mother, which is also picked up by Anselm, but I would still argue that childbearing and the pain and suffering that are connected to it are clearly connected to Eve and women and are used more often as a means of establishing authority by women. 
were the cause of a significant amount of mental illness among women" (47). ${ }^{21}$ Childbirth was, thus, one of the reasons why women were often seen as chronically sick and weak. Indeed, maternal mortality figures from the period reveal the dangers that women were exposed to. According to Roger Schoefield, who looked at maternal mortality over three centuries, the rate was just over 10 deaths per 1000 baptisms in the first half of the seventeenth century over thirteen parishes in England (250). This number rose to 15.7 in the second half of the seventeenth century (248), while in London it was even 23.5 per 1000 baptisms (233). Even though Schoefield maintains that childbearing was a "less mortal occasion than we may have been inclined to believe" (260), it was an additional cause of death that was exclusive to women. The numbers, particularly in London, in the late seventeenth century were quite high and women must have seen it as a serious and dangerous burden that they needed to endure.

Moreover, even if childbirth did not end in death, women suffered not only the pains of bearing children, but also pain and sickness during and after pregnancy. ${ }^{22}$ Richard Baxter (1615-1691) sums up women's lives in his second part or "Family Directory" of his Christian Directory in the following way:

Women especially must expect so much suffering in a married life, that if Cod hat not put into them a natural inclination to it, and so strong a love to their children, as maketh them patient under the most annoying troubles, the world would ere this have been at an end, through their refusal of so calamitous a life. Their sickness in breeding, their pain in bringing forth, with the danger of their lives, the tedious trouble night and day which they have with the children in their nursing and their childhood; besides their subjection to their Husbands, and continual care of family affairs; being forced to consume their lives in a multitude of low and troublesome businesses. (Part II, Chap. 1, p. 8)

See also Michael MacDonald: "Women sought medical treatment more often than men because they were more often ill. In addition to the afflictions men bore, women also suffered from diseases that tormented only their sex. [...] Childbirth without anaesthesia or asepsis was excruciating and dangerous: Difficult and botched deliveries often left women mangled, sterile, or lame - if they survived the infections that appear commonly to have followed dangerous labors" (38). of well-being and joy, pregnancy in the sixteenth and seventeenth centuries was correlated with physical discomfort and mental unease" (45). 
In Baxter's view, women's life is marked by subjugation to their husbands, sickness while being pregnant and the pains and dangers to their lives while giving birth. Baxter also mentions the burdens that women bear in nursing their children as well as in the latter's upbringing. It seems clear from all these texts ${ }^{23}$ that women were undoubtedly anxious about childbearing.

Thomas Bentley, author of The Monument of Matrones, includes over forty prayers for women before, while and after childbearing. Throughout the prayers, it becomes clear that both pain and the danger of imminent death are at the forefront of women's minds. Interestingly, many of these prayers are also connected to the aforementioned themes, namely, Eve's transgression and punishment, redemption, and Christ's suffering on the cross. Suffering pain in childbirth is the consequence of sin and as such must be endured humbly, as the following prayer shows:

I acknowledge, O Lord, that iustlie for our sinfull transgression of thy commandements, thou saiedst unto the first woman, our grand-mother Eve, and in hir to us all; I will increase thy sorowe, when thou art with child: with paine shalt thou bring foorth thy children. All our paines therefore that we suffer in this behalfe, are none other thing, but a woorthie crosse laid upon us by thy godlie ordinance, to the which with hart \& mind I humblie submit my selfe, trusting surelie, and being fullie persuaded in my faith, that thou callest none into perill and danger, but both thou canst, and wilt at convenient season deliver them. (96)

Apart from the acknowledgement of Eve's transgression and punishment and the pain that must be suffered humbly, Christ is implicitly evoked through the bearing of this cross. There are other prayers that are much more explicit in connecting childbirth with Christ's suffering. The end of the next prayer even calls to mind affective piety and the mystic's dwelling on the wounds of Christ: "Give me power to pitch my confidence onelie and alone in the bloudie

23 In addition to its frequent appearance in texts, Judith W. Hurtig discusses death in childbirth as represented on seventeenth-century English tombs. She states: "Although it had always been common that women and their children died in childbirth, it was not until the late sixteenth and early seventeenth centuries in England that this cause of death was made the focus of the imagery on their tombs. [...] It is not the intention here to argue that there was an underlying change in attitude towards death in childbirth, but rather to indicate that the appearance of these funerary monuments occurred at a time when childbirth and its perils appear to have been the subject of particular concern and anxiety" (603). 
wounds of Christ Jesus, to whome in this my distresse I flie, and appeale for remedie and comfort. Grant this $\mathrm{O}$ gratious God, which livest and reignest world without end, Amen" (107). The connection becomes even clearer when Bentley encourages women "In long and sore labour" to say Psalm 22 of David, which he calls "The complaint of Christ on the Crosse" (109). Although much of the Psalm is retained in Bentley's prayer, he undertook some interesting changes such that it would pertain to a woman in childbirth. Male pronouns turned into female ones and the line "I am a worm, and no man; a reproach of men, and despised of the people" becomes "I seeme rather to be a worme than a woman, the doonghill of Adam and Eve, the outcast of the vulgar people" (110), while Christ on the cross becomes a woman in labour: "My God, my God, why hast thou forsaken me? It seemeth that I shall not obteine deliverance, though I seeke it with lowd cries" (109). Here, Bentley clearly plays with the double meaning of "deliver" and thus closely connects giving birth and redemption. Anselm, as we have seen, already associated Christ's suffering on the cross with giving birth to a redeemed humankind and Bentley's changing of Psalm 22 links women's suffering in childbearing with Christ and redemption for themselves as well as for humankind. ${ }^{24}$

However, even though it seems clear that the suffering in childbearing is to be seen as just punishment for Eve's transgression and is to be endured humbly, several of Bentley's prayers speak of women's anxiety and pain:

How is it Lord, that for no intreatie thou wilt not deliver thine hand-maid from such indurable greefes? How long shall I suffer the paines of the birth, and the anguish of the travell? How long Lord shall my bowels thus sound like an harpe, my bones and sinewes be racked asunder, and mine inward parts be thus greevouslie tormented for my sins. [...] Oh Lord, spare me, oh deare God, have mercie upon me, and my babe! Shall I be the grave of my child? Shall I give death the fruit of my bodie, for the sins of my soule. (115)

24 As seen in 1 Timothy 2:13-15, women are saved through childbearing and this of course goes hand in hand with the command "increase and multiply." Bentley has another prayer that breaks down these connections: "In the beginning of the world, $\mathrm{O}$ father of heaven, after thou hadst formed man of the slime of the earth, and yet prince over all creatures, it pleased thee of thy goodnes to create a woman of his side, aswell for his solace, as for the continuance of his seed: it was thy word unto them, Increase \& multiply. This increase was easie, but mother Eve hath made it hard, by passing the bounds of thy will, to all hir posteritie; so that the woman conceiveth and bringeth foorth in great paine, and painefull travell, the fruit of hir wombe" (127). 
The continuously asked questions show the woman's pain rather than her patience and the mentioning of her bowels, bones and sinews draws a very graphic picture of her suffering. Jane Sharp (fl. 1641-1671), who wrote a textbook on midwifery in the seventeenth century, comments on this pain: "Childbearing is so dangerous that the pain must needs be great, and if any feel but a little pain it is commonly harlots [...] these doubtless are the greatest of all pains women usually undergo upon Earth" (170). ${ }^{25}$

Aside from the references to pain in Bentley's prayer, the question "Shall I be the grave of my child?" indicates that the fear of death was indeed part of the mindset before and while giving birth. This can be seen, for instance, in several writings by women, who were not only thinking about the death of their child, but also about their own possible demise. Anne Bradstreet (16131672), for instance, wrote a poem to her husband entitled "Before the Birth of one of her Children":

All things within this fading world hat end,

Adversity doth still our joyes attend;

No tyes so strong no friends so clear and sweet,

But with deaths parting blow is sure to meet.

The sentence past is most irrevocable,

A common thing, yet oh inevitable;

How soon, my Dear death may my steps attend,

How soon't may be thy Lot to lose thy friend,

We both are ignorant, yet love bids me

These farewell lines to recommend to thee (1-10, p. 134-135)

Bradstreet here bids farewell to her husband as she assumes that she is not going to survive giving birth to her child. She asserts that death is common and inevitable in principle but the birth of her child occasions her to write this poem and to imagine her own death. Furthermore, she not only humbly accepts her death, but she also shows sadness at the end of the poem, where she

Even though Jane Sharp describes all the ways in which childbirth can be dangerous and painful in a more or less scientific fashion, she also states: "The accidents and hazards that women lye under when they bring their Children into the world are not few, hard labour attends most of them, it was that curse that Cod laid upon our sex to bring forth in sorrow, that is the general cause and common to all as we descended from the same great Mother Eve, who first tasted the forbidden fruit" (167). Thus, she too continues the discourse about Eve's transgression and just punishment that has to be endured by all women. 
asks her husband to "look to her little babes her dear remains" (22) and "with salt tears this last Farewel did take" (28). Childbirth clearly caused anxiety and that fear was frequently reflected in women's writing.

Another such example is Elizabeth Jocelin (1596-1622), who wrote a onehundred-and-fourteen-page instruction ${ }^{26}$ to her unborn child, because she was certain that she would die in childbirth. Elizabeth writes in a letter to her husband: "Mine owne deare love, I no sooner conceived an hope, that I should bee made a mother by thee, but with it entred the consideration of a mothers duty, and shortly after followed the apprehension of danger" ("The Letter"). Even in life, Elizabeth writes as though from the grave: "It may seeme strange to thee to recieve these lines from a mother, that died when thou wert borne" ("The Approbation"). Elizabeth was sure enough of her death that she felt the need to write these meditations for her child, in order to be able to have a say in how the child was raised and educated. Thomas Goad, who published The Mothers Legacie to her Unborne Childe after Elizabeth's death, clarified that shortly after Elizabeth gave birth to her child, she died of a fever.

In "The Approbation," Goad describes the circumstances of the meditations, and his descriptions are telling:

when as the course of her life was a perpetuall meditation of death, amounting almost to a propheticall sense of her dissolution, even then when she had not finished the 27 yeere of her age, nor was oppressed by any disease, or danger, other than the common lot of child-birth, within some moneths approaching. Accordingly when she first felt her selfe quicke with childe (as then travelling with death it selfe) shee secretly tooke order for the buying a new winding sheet: thus preparing and consecrating her selfe to him, who rested in a new Sepulcher wherein was never man yet layd. And about that time, undauntedly looking death in the face, privatly in her Closet betweene Cod and her, shee wrote these pious Meditations.

Goad mentions her almost prophetical ability to foretell her own death as soon as she becomes aware of her pregnancy. Interestingly, even though Goad describes childbirth as a "common lot," he nevertheless lists it along with disease and danger, pointing to the fact that childbirth is seen as both dangerous and having an association with illness. Furthermore, his addition in parentheses

26 This text, for instance, also shows that childbirth was clearly a topic in the seventeenth century, as it "appeared in seven further editions in the seventeenth century alone" (Brown). 
"as then travelling with death it selfe," turns her baby into the harbinger of death and death itself. The vocabulary used in several of these texts and poems is often rather graphic, portraying the women as graves or the children as death. Goad, however, also links Elizabeth to Christ in quoting the Bible in connection to her buying a new winding sheet and preparing herself to die. The Biblical quote can be found in the following context: "Then took they the body of Jesus, and wound it in linen clothes with the spices, as the manner of the Jews is to bury. Now in the place where he was crucified there was a garden; and in the garden a new sepulchre, wherein was never man yet laid" (John 19:40-41). Thus, in choosing this quote to speak of Christ, Goad both links Christ's linen clothes with Elizabeth's winding sheet and evokes his crucifixion, thereby once more linking childbirth to Jesus' suffering on the cross as is the case in so many other texts.

Mary Carey (b. c. 1609, $d$. in or after 1680) wrote several poems on the death of her children. A common denominator of these poems is Carey's humble acceptance of these deaths and her praising of Christ. In this vein, she writes: "My lord hath called for my sonne/ my hart breth's forth; thy will be done" (1-2,"On the death of my $4^{\text {th }}$, \& only Child, Robert Payler," p. 156) or

I thought my all was given before

But mercy ordred me one more:

$[\ldots]$

My Dearest Lord; hast thou fulfill'd thy will,

Thy hand maid's pleas'd, Compleatly happy still: (1-2, 9-10, "The death of my $4^{\text {th }}$ sonne and $5^{\text {th }}$ Child Perigrene Payler," p.157-58)

Despite the deaths of several of her children, she considered it to be God's will and was still "happy" to serve Him.

Interestingly, one of her longer poems is about a stillborn child and is called "Upon ye Sight of my abortive Birth ye 31th: of December 1657." Carey similarly stresses her humble acceptance:

What birth is this; a poore despissed creature?

A little Embrio; voyd of life, and feature

[...]

This is no lesse; ye same God hath it donne;

Submits my hart, thats better than a sonne:

In gieveing; taking; stroking; striking still;

His Glorie \& my good; is. his. my will: (1-2,9-12, p. 158) 
This passage shows that even though stillborn, this child and its death are in accordance with God's plan and will. However, Carey also links the death of her child to her own sins here, (19; p. 159) asking: "I only now desire of my sweet God/ the reason why he tooke in hand his rodd?" (17; p. 159).

Much like Margery Kempe, who transcribes entire dialogues between herself and God, Carey also lets God speak in her poem. In answer to her question, God says:

Whose taught or better'd by ye no Relation;

Thou'rt Cause of Mourning, not of Immitation:

Thou doest not answere that great meanes I give;

My word, and ordinances do teache to live: (46-49, p. 160)

With these rather harsh words, Carey makes clear that the stillborn child is a punishment for not living according to God's word. Despite starting her poem positively in saying that God has gained one more child in heaven to praise him (8, p. 158), she still assumes it to be a punishment for her sins. Carey accepts God's will but at the same time bargains with Him in these poems. In the poem "On the death of my $4^{\text {th }}, \&$ only Child, Robert Payler," for instance, she expresses the desire to exchange her dead son with Christ:

But if I give my all to the

Lett me not pyne for poverty:

Change with me; doe, as I hve done

Give me thy all; Even thy deare sonne: (5-8, p. 156)

In this exchange, Carey links herself to God by making an analogy to His sacrifice and her own. She gives a child to God and in return receives Christ. In doing so, Carey almost reverses the order of God's sacrifice of His Son and puts her own sacrifice first.

In the poem about her stillborn child, furthermore, she tries to bargain after the words spoken by God. This time, however, her wish is another one:

I'm a branch of the vine; purge me therfor;

Father, more frute to bring, the heertofore;

[...]

Lett not my hart, (as doth my wombe) miscarrie;

But precious meanes receive, lett it tarie;

[...] 
Thy quickning Spirit unto me convey;

And therby Quicken me; in thine owne way: (70-71, 74-75,84-85, p. 160-161)

In the latter section of the poem, Carey tries to reverse God's words and be the source of imitation, rather than mourning. In calling herself "a branch of the vine," Carey makes it clear that she still lives God's word and will. Furthermore, she asks God to quicken her with his Holy Spirit. Playing with the double sense of the word 'quicken' and exchanging her heart with her womb, she substitutes living fruit, namely her children, for more spiritual ones. Instead of giving birth to more children, Carey produces texts and poems, which will have "Gosple shape, \& sute; / my meanes, my mercyes, \& be pleasant frute" (76-77, p.161). Carey thus manages to use conventional symbolism here, such as the humble acceptance of and the punishment for her own sins, in order to empower herself and her texts. Quickened by God's Spirit, her texts gain another level of authorisation and Carey will not be the source of mourning but of imitation. ${ }^{27}$

As a consequence, childbirth, the punishment for original sin, is also associated with Christ's suffering on the cross and redemption. These female visionary writers negotiate these notions in order to produce writings and attain authorship for their texts. Women writers, such as Bradstreet, Jocelin and Carey, try to reconcile themselves with the perceptions of illness and transgression and the connection to Christ's suffering and redemption. Through the link to Jesus, these women are able to legitimise their voices as well as their writings. Similar to the link between childbearing and Christ, the next section will focus on other forms of imitation.

\subsection{Imitatio Christi}

Illness marks a rite of passage to a visionary stage and allows people to see God's workings through the sickness and healing of the visionaries. Throughout Trapnel's writings, and also in Margery's Book, ${ }^{28}$ illness and weakness is

27 See also Louis Schwartz's discussion of the poem. He, for instance, maintains: "I would argue that this poem provides us with a remarkable example of the imaginative power a woman could wield with instruments that in other contexts were designed to simply admonish her" (65). mech that sche was anoyntyd for dowt of death. [...] And than owr Lord Jhesu Crist 
mentioned again and again in order to demonstrate God's works. Another look at the above cited passages, in which Julian, Margery or Anna lie sick in bed, shows that the bystanders are witness to a serious illness that will likely end in death but the visionary is suddenly healed. Thus, the contrast between the initial visible weakness and the subsequent sudden strength gained through God serve as proof of the visionary's divine bond. Indeed, at the end of The Cry of a Stone, the scribe stresses exactly this point as a final confirmation of Trapnel's status as a prophet. These last words are worth quoting in full:

Herewith she closed, having layn in bed eleven dayes and twelve nights together; in all or most of which time her weakness of body was such, that after she had kept her bed the first two dayes and nights, being raised up wile her bed was made, she was not able to go, but as she was carried in a Chair to the fire, and was ready to faint in place, though they made hast to make her bed ready for her, notwithstanding this weakness, after she had kept her bed II. dayes together, without any sustenance at all for the first five dayes, and with onely a little toste in small beer once in 24 hours for the rest of the time, she rose up in the morning, and the same day travelled on foot from White-Hall to Hackny, and back to Mark-Lane in London, in health and strength. (76)

Trapnel has spent eleven days in bed and barely eaten. They even have to carry her across the room, and she nearly faints there on a chair from weakness. However, in the morning, after all these days of weakness, she simply rises up and is able to travel approximately ten miles through London. For those who witnessed Trapnel's recovery, as well as those reading the account in The Cry of Stone this must have seemed like nothing short of a miracle.

In Anna Trapnel's Report and Plea, ${ }^{29}$ which reports her journey to Cornwall, her arrest and trial, her return to London as well as her imprisonment in Bridewell, Trapnel makes explicit the connection between her weakness, strength and the Lord: "Then after that singing, I was put to bed, being weak

seyd to hir in hir sowle that sche schul [not] dey yet, and sche wend hirselfe that sche schulde not a levyd, for hir peyn was so gret. And hastily aftyrwarde sche was heyl and holy."

29 The page numbering in Report and Plea is not straightforward. After page 28 it goes back to 25 again. Page numbers are shown as in the manuscript. When quoting from 25-28 pages are marked as for example 25.1 or 25.2 to avoid any confusion. 
in body and head, between two friends, where I lay and prayed till the morning; and coming into my ordinary capacity, I rose and had strength of body [...] This I mention, to advance Christ, and not for any by-end" (5-6). The bodily weakness that is often associated negatively with women is here turned into strength. Trapnel shows to her two friends, as well as to the readers of the Report and Plea that in spite of the fact that she is weak, she is able to gain strength through Christ. In the eyes of an outsider, this can serve as proof of God's grace as well as of the intimate bond between the visionary and the Creator. Hence, women's weakness is literally and symbolically turned into strength.

In addition, weakness and illness are also associated with suffering. As with the suffering felt in childbirth, pain, weakness of body, disease and, indeed, any kind of suffering become important topics for several of these visionaries. However, far from being perceived as negative, suffering is used as further proof of the intimate bond between the visionary and Christ, and even as a means by which to be compared to him. The one self-inflicted suffering that is quite common with women visionaries is fasting and bodily penance. Throughout Trapnel's writings, it is pointed out that she eats almost nothing and is still able to live and function as a vessel for God. In the passage mentioned above, the scribe, in describing her eating and drinking habits in so much detail, not only makes sure to stress these miraculous moments of gaining strength through Christ, but also captures the astonishment of the onlookers who witness her during her trances. Again, the performance of not eating and drinking in company over a long period of time while remaining healthy enables Trapnel's status as a prophet.

Fasting and bodily penance are also themes that arise again and again in Margery's Book. As in Trapnel's case, Margery's fasting and bodily penance are performed in public: "Sche yaf hir to gret fastyng and to gret wakyng; sche roos at ii or iii of the clok and went to cherch, and was ther in hir prayers onto tyme of noon and also al the afyrnoon. And than was sche slawnderyd and reprevyd of mech pepul for sche kept so streyt a levyng" (64). Margery is even slandered because of her strict life, indicating the jealousy of others who are not able to emulate her. On several occasions, she reminds those around her such as her husband or people with whom she goes on pilgrimages of her intimate relationship with Christ in that she is able to fast and lead a strict life in contrast to their lives. It seems that fasting and bodily penance are only possible through special grace and help from Christ and, thus, both Trapnel and Margery are singled out in the public eye. Interestingly, these women 
prophets do not concentrate on the penance of their bodies as, for instance, is prescribed by Hilton in the above cited passage. Of course, they stress their sinfulness and nothingness repeatedly but the chastising of the flesh in order to rule over their sinful bodies seems to be of secondary importance. Trapnel, for her part, does not generally connect her fasting with bodily penance at all. Instead she uses it, as in the above mentioned passages, to show the world the special bond between her and Christ. In a similar fashion, Margery also comments on her sinfulness and turns her penance into a public spectacle, thereby achieving the same goal as Trapnel. Consequently, bodily penance and suffering are marked as granting authority and proving the visionaries' special connection to God.

Another bodily spectacle in terms of suffering is Margery's gift from God, namely to cry and weep in remembrance of Christ's Passion. In chapter 28, where she had "the fyrst cry that evyr sche cryed in any contemplacyon" (163), the word cry in its various forms appears no fewer than thirteen times in sixtysix lines. In the next chapter, where the different places of Christ's Passion are briefly listed, the words wepyng, sobbyng and cryed are mentioned eleven times in only sixteen lines. However, this gift is the main reason why most of her contemporaries in ecclesiastical or worldly offices believe her to be either hypocritical or mad. From this point onwards she cries so often ("onys sche had xiiii on o day") and everywhere ("sumtyme in the cherch, sumtyme in the strete, sumtym in the chawmbre, sumtyme in the felde" (164-65)) that references to it reappear in almost all other chapters in the Book. As was the case with her bodily penance, those around her slander her for it: "And this maner of crying enduryd many yerys aftyr this tyme, for owt that any man myt do, and therfor sufferyd sche mych despyte and mech reprefe. The cryeng was so lowde and so wondyrful that it made the pepyl astoynd" (163).

As a result, Margery repeatedly needs to legitimise this aspect in the Book and, at one point, she gains authority in a very significant way. The priest who writes down Margery's words is sometimes shown to be deeply sceptical about her. In chapter 62, he once again does not believe her until he is convinced by God to compare Margery with other saints. He then begins listing several saints such as Marie d'Oignies (ca. 1177-1213), who herself wept so many tears that she was unable to hear the Passion of Christ spoken or performed. Thereafter, texts such as Stimulus Amoris by Bonaventure, Incendio Amoris by Richard Hampole are listed. Reference is also made to Elizabeth of Hungary (1207-1231) who also cried loudly in devotion to Christ. As a result: "Than he levyd wel that the good woman, which he had beforn lityl affeccyon to, myth 
not restreyn hir wepyng, hir sobbyng, ne hir cryying, whech felt meche mor plente of grace than evyr dede he, wythowtyn any comparison. Than knew he wel that God yaf hys grace to whom he wolde" (294). Thus, the scribe of her Book and the reader are convinced of Margery's true devotion to Christ and of her gift, which she is unable to restrain. Her suffering is made visible by her tears and her body again takes centre stage in showing her intimate bond with Christ.

Tears and crying have long been deemed to be female attributes, as can be seen in relation to Margery, Marie d'Oignies and Elizabeth of Hungary. This still held true in the seventeenth century when John Featley, a Church of England clergyman, wrote A Fountaine of Teares for Elizabeth Keate. He explains the decision to write his book in the following way: "I was first invited to this taske by the moanes of a gracious and veruous gentle-woman, who much complained that her sexe was so much neglected by Divines, that they had not penned devotions for all their severall sufferances that are common to many" "To the Reader"). He thus dedicates his work to her and "For her deere sake these Soliloquies and Prayers were fitted for Females, and taught to speake in the persons of the Weaker vessells" ("To the Reader").

Here, Featley mentions several stereotypes that supposedly characterise women, such as crying or women being the weaker vessels who are in need of prayers fitted for them. In the first chapter of his book, Featley maintains that a "teare of a faithfull soule which floweth from the conscience of evill, purifieth the conscience" (2). As a result, tears can be purifying, especially when one cries because of one's sins and iniquities and makes these tears a visible part of one's repentance. As a further positive example of crying, Featley mentions Mary Magdalene, who cried at the feet of Christ and washed his feet with her tears (2). The example of Mary Magdalene is also taken up by Margery Kempe to justify her own tears. Shortly after Margery receives her gift in Jerusalem, the Virgin Mary tells her not to be ashamed of her crying: "no mor than I was whan I saw hym hangyn on the cros - my swete sone, Jhesu - for to cryen and to wepyn for the peyn of my swete sone, Jhesu Crist; ne Mary Mawdelyn was not aschamyd to cryen and wepyn for my sonys lofe" (171). Furthermore, in Margery's mind, weeping is strongly connected to prayer (360), just as it is for Featley, who calls the Teares of godly sorrow " $[t]$ he sanctified Ejaculation to precede each severall meditation, and prayer" (1). As distinctly female a feature as tears seemingly are, they are not a sign of weakness. Being able to cry for one's sins as well as for Christ's suffering substantiates the bond between the supposedly weaker vessels and Christ. 
In addition to the public spectacle of their suffering, the ability to bear this suffering humbly and in any form makes these women comparable to Christ. In this regard, there are parallels to the links felt in affective piety. The humble acceptance of suffering can be seen, for instance, in the texts about childbirth. Moreover, Trapnel and Margery repeatedly stress their joy in suffering in the name of Christ. Trapnel knew that she would meet a great deal of resistance and many people who would despise her on her journey to Cornwall. However, she states: "it made my heart much affected with my journey, and my Spirit leapt within me, and rejoyced that I was come into a country where I should suffer for the testimony of Jesus" (Report and Plea 13). The more she is despised and the more she bears her suffering in humility, the more she rises in God's esteem. As she herself tells us: "thus they spit forth venome against me; but it did me no hurt, because my Father made it work for good; my joy was not lessened, but increased" (Report and Plea 18). In fact, a clear connection to Christ's sufferings is even made: "That so I might all my dayes be willing to take up the Crosse of Christ, and follow him, whether so ever he would have me, either to do or suffer" (Report and Plea 45). Again, the suffering of these women is compared to Christ's crucifixion and everything that is said negatively to them and about them makes them rise in God's grace.

Of course, this is not particularly specific to women. Humility and suffering in the name of God or Christ applies to all Christians, male and female and stems from the Bible. Luke 6:22-23 states: "Blessed are ye, when men shall hate you, and when they shall separate you from their company, and shall reproach you, and cast out your name as evil, for the Son of man's sake. Rejoice ye in that day, and leap for joy: for, behold, your reward is great in heaven." ${ }^{30}$ The suggestion is that the more one suffers for Christ's sake, the more one is rewarded in heaven. This concept is then taken up throughout history, for instance, by Thomas à Kempis. He is most probably the author of Imitatio Christi, which was written in the Netherlands between 1420 and 1427 and which went through forty-six editions in six translations before 1640 ("Introduction" xiii). His book is a manual for emulating Christ in order to live the perfect life in God's name and will. In this regard, Kempis says: "If thou canst not behold high and heavenly things, rest thou in the passion of Christ and dwell willingly in His sacred wounds. For if thou devoutly fly to the wounds of Jesus, and the precious marks of the nails and the spear, thou shalt find great comfort in

30 See also Matthew 10:22: "And ye shall be hated of all men for my name's sake: but he that endureth to the end shall be saved." 
tribulation, nor will the slights of men trouble thee much, and thou wilt easily bear their unkind words" (Chapter IV, Book II). Here, Kempis connects the humble acceptance of tribulations and suffering in the name of Christ to the mystics' affective piety.

Thinking about the Passion, therefore, both leads one to a higher contemplative level and gives one comfort to bear all kinds of suffering in the world. Furthermore, Kempis maintains that Christ was also despised and rejected while on earth and that we should therefore not complain but instead bear the suffering humbly and patiently (Chapter V, Book II). Calvin talks about Jesus' suffering in a similar way in his Institutes, stating that:

as he passed to celestial glory through a labyrinth of many woes, so we too are conducted thither through various tribulations. [...] How powerfully should it soften the bitterness of the cross, to think that the more we are afflicted with adversity, the surer we are made of our fellowship with Christ; by communion with whom our sufferings are not only blessed to us, but tend greatly to the furtherance of salvation. (Chapter XIII, Book III, 431-32)

Following Christ's example and suffering in his name is rewarded and, at the same time, shows the world that one is connected to the Lord.

Even though the humble acceptance of suffering in the name of Christ is not specific to women alone, they use it in order to legitimise themselves in a way that is specific to their gender. Their suffering is often connected to their bodies and, thus, to other themes, such as sin and redemption. This holds true for Margery. Throughout her Book, people speak ill of her, she is slandered by her fellow pilgrims, attacked as a witch, a Lollard, a hypocrite and much more. The connection between this slander and her being rebuked, as well as God's love for her because of this, is established very early on in her text:

Sche was so usyd to be slawndred and repreved, to be cheden and rebuked of the world for grace and vertu wyth whech sche was indued thorw the strenth of the Holy Cost, that it was to her in a maner of solas and comfort whan sche sufferyd any dysese for the lofe of Cod and for the grace that Cod wrowht in hyr. For evyr the mor slawnder and repref that sche sufferyd, the mor sche incresyd in grace and in devocyon. (43-44)

In addition to references to suffering and to the subsequent increase in grace and devotion, Margery makes sure to include the fact that she is rebuked by others because of the virtue and grace that the Holy Ghost works in her. 
Thus, she manages to legitimise all the behaviour for which she is rebuked throughout the Book.

Interestingly, this is also a topic that Margery discusses with Julian of Norwich during her visit. Julian tells her that she should not fear the language of the world "for the mor despyte, schame, and repref that ye have in the world, the mor is yowr meryte in the syght of God" (122). Furthermore, the analogy between Margery and Christ's crucifixion is again made explicit in the following speech of Christ's: "for as long as he spekyth ageyns the, he spekyth ageyns me, for I am in the and thu art in me. And herby mayst thow knowyn that I suffyr many schrewyd wordys, for I have oftyntymes seyd to the that I schuld be newe crucifyed in the be schrewyd wordy, for thu schalt non otherwyse ben slayn than be schrewyd wordys sufferyng" (189). The slandering words against Margery re-enact a crucifixion of her own, turning her into Christ and vice versa. Through the constant repetition of this theme, Margery is able to legitimise her behaviour, even though that behaviour is eccentric and a topic of discussion among other citizens or fellow travellers. She cannot be rebuked or insulted without increasing her grace and devotion. Whatever her behaviour is, she is able to justify it.

As we have seen, negative terms related to the female body, such as transgression, sin, weakness and illness, are used by these female visionary writers in order to legitimise their writings. The often negative connotations stem, for instance, from religious writings. In many of these texts, such as the Bible or works by Augustine, Rolle and Hilton, the body is strongly connected to sin and has to be repressed or overcome. Even though the body does play an important role in affective piety, in as much as the mystic thinks about the Passion and Christ made flesh in an explicitly physical way, the discarding of the body is still a prerequisite in order to gain a higher contemplative level. The subordination of the body to the spirit, furthermore, often goes hand in hand with an analogous subordination of women to men and interpretation of the imago dei. From there, the negatively connoted body is often associated directly with women, characterising them as sinful and passionate. Interestingly, Julian of Norwich also uses the bipartite soul system in her writing, but, for her, God is both in the 'substance' and in the 'sensuality'. As we will see in the next chapter, in Julian's perception of the imago dei, sensuality, and thus the body, also plays an important role in our salvation. In general, stressing the positive aspects of the body is far more important for women than men and the visionaries examined here focus heavily on the body and use it to their advantage. Affective piety, for instance, gives both Julian and Margery 
an opening for their 'sinful' bodies to connect to Christ's body and to gain an intimate bond and a higher spiritual level that would otherwise be denied to them. In her text, Margery draws heavily from the mystical tradition, including Hilton and Rolle, but finally surpasses those writers. The fire of love that Rolle describes as the highest level of contemplation and thus as difficult to attain is felt by Margery for sixteen years even though she is not a recluse and is quite mobile. By using affective piety and their bodies to their advantage, both Margery and Julian therefore succeed reversing negative stereotypes related to the female body.

In several instances, moreover, the female visionaries use an illness as a rite of passage to their prophetical status, which is clearly different from the approach taken by male authors. As women are often seen as prone to weakness and illness, this becomes an important topic in several of these female visionaries' writings. Trapnel, Margery and Julian all nearly die of an illness, which is the beginning of their visionary status. One 'sickness' that affects only women is childbirth of course. The suffering and pain that women experience in childbirth is deemed to be the punishment for Eve's transgression, but it is also her redemption. Furthermore, through its suffering and redemptive character, childbearing is often associated with Christ's suffering on the cross. Continuing the tradition from Paul and Anselm, Julian pictures Christ as a mother. In her case, however, she goes one step further and includes him in her theodicy as both a mother who gives birth to redeemed humankind and as a nursing mother who raises and looks after her children. Many prayers, texts and poems were produced on the topic, whereby Eve's transgression and the analogy to Christ's suffering were still important parts of the discussion. Carey, for instance, sees the death of her child as a punishment for her own sins, but is still able to bargain with God at the end of her poem. In turning her womb into her heart and substituting living fruit for spiritual ones, she empowers herself as well as her texts. Instead of giving birth to children, she now gives birth to a poem, quickened by the Holy Spirit.

Moreover, through their weak bodies, these women are able to show the people around them and their readers the intimate bond that they have with God. Be it an illness, a weak disposition, fasting or bodily penance, Margery or Trapnel show the world that they have special grace from God, as they are able to suddenly walk many miles after being weak or sick. Even Margery's abundant crying and weeping is proof of her status as a visionary. Thus, these women's whole bodies become a visual sign of God's grace, turning the negative labels associated with the female body into markers of authorisation. 
The more these women suffer, the more they are able to justify their writings. Suffering in the name of Christ and bearing it humbly forms another part of the comparison to the Lord. Taking up the concept from the Bible, namely "Blessed are ye, when men shall hate you [...] reproach you [...] for the Son of man's sake. Rejoice ye in that day, and leap for joy: for, behold, your reward is great in heaven" (Luke 6:22-23), Trapnel and Margery are able to profit from being reproached and slandered. In spite of the negatively connoted connection of female bodies to sin, weakness and illness, these women are able to gain agency through these stereotypes and mobilise their bodies to their advantage. In the next chapter, we will see these women visionary writers negotiate further negative epithets that should have, but in truth did not prevent them from writing, speaking in public, or participating in political discussion. 
